\title{
Migration speeds among eleven species of long-distance migrating passerines across Europe, the desert and eastern Africa
}

\author{
Elizabeth Yohannes, Herbert Biebach, Gerhard Nikolaus and David J. Pearson \\ E. Yohannes (correspondence), Max Planck Institute for Ornithology, Behav. Ecol. \& Evol. Genetics, P.O. Box 1564, D 82305 Starnberg \\ (Seewiesen), Germany. E mail: yohannes@orn.mpg.de. H. Biebach, Max Planck Institute for Ornithology, Von der Tann Str. 7, D 82346, \\ Andechs, Germany. G. Nikolaus, Padingbutteler Strich 36, 27632 Padingbutteler, Germany. D. J. Pearson, Lupin Close Reydon, \\ Southwold, Suffolk IP18 6NW, UK.
}

\begin{abstract}
Based on phenology, passage and median dates gathered from large number of study sites, we measured autumn and spring migration speeds of eleven long distance migratory passerines in four different ecogeographic sectors: Europe, desert, north eastern and eastern Africa. Results demonstrate that, during the southward autumn migration, late departing species, such as lesser whitethroat Sylvia curruca, garden warbler S. borin, spotted flycatcher Muscicapa striata, whitethroat S. borin, and willow warbler Phylloscopus trochilus cover their migration route with a slower average migration speed across Europe than do early migrating species. During spring migration, late departing species (marsh warbler Acrocephalus palustris, garden warbler, spotted flycatcher, red backed shrike Lanius collurio) across north eastern Africa showed a higher speed than early migrating species. Our results show overall shorter migration duration estimates in spring than autumn. Sector wise seasonal comparisons of duration indicate that migration journey in the African and desert sectors are covered in a relatively shorter time in spring than in autumn. Periods required to cover the distance between northern latitude breeding grounds and desert during both seasons were equivalent.
\end{abstract}

It is commonly accepted that birds modulate their migra tion with respect to time, energy and predation risk (Alerstam and Lindström 1990, Lindström and Alerstam 1992, Weber and Houston 1997, Weber et al. 1998, Alerstam 2003). In an optimal course of avian migration, all other factors being equal, time minimizing birds have the advantage of arriving at required wintering, moulting or breeding destinations earlier than competitors. Particularly in spring, where the breeding periods are short, time minimization could be crucial for reproduction. In such cases, evolution would favour an overall high migration speed that minimizes both flight and stopover time and thus facilitates early arrival at breeding locations.

High speed of migration could have critical fitness associated costs (e.g. reduced survival). Hence, not all species migrate at a high speed and different species commence migration at different times. Early departing birds might reach a required destination earlier than late departing species. This argument leads to the question of whether species that commence migration late migrate with a faster speed. Late departing species may not have to 'pace themselves' but might migrate with a faster speed for the entire migration (sprint) and arrive earlier or at least at an optimally comparable time with others.

Long distance migrating species that breed in the north ern latitude and winter in tropical regions are exposed to different habitats and ecological conditions along their migration routes. Migrating birds need to optimally mod ulate their travel costs and benefits of time, energy and safety according to specific ecological and geographical demands en route. Hence, migration speed might vary between different geographic sectors along the migration route.

In this study, we compared the speeds of migration in 11 passerine species during autumn and spring using speed estimates derived from the temporal patterns of migration (arrival and/or passage dates; Hildén and Saurola 1982, Ellegren 1990, Fransson 1995) along the eastern Africa migration route. The main objectives of the study are to compare the seasonal variation in the speed of migration in four different geographic sectors (Europe, desert, north eastern and eastern Africa) along the route and to measure the sector wise difference in migration speed between the different species depending on whether the species are on early or late schedule of migration. Based on total duration estimates, we also compared sector wise differences between spring and autumn migration speeds.

\section{Methods}

\section{Data collection}

Data for speed estimates were obtained from both pub lished and unpublished sources on ringing sites (Fig. 1) and 


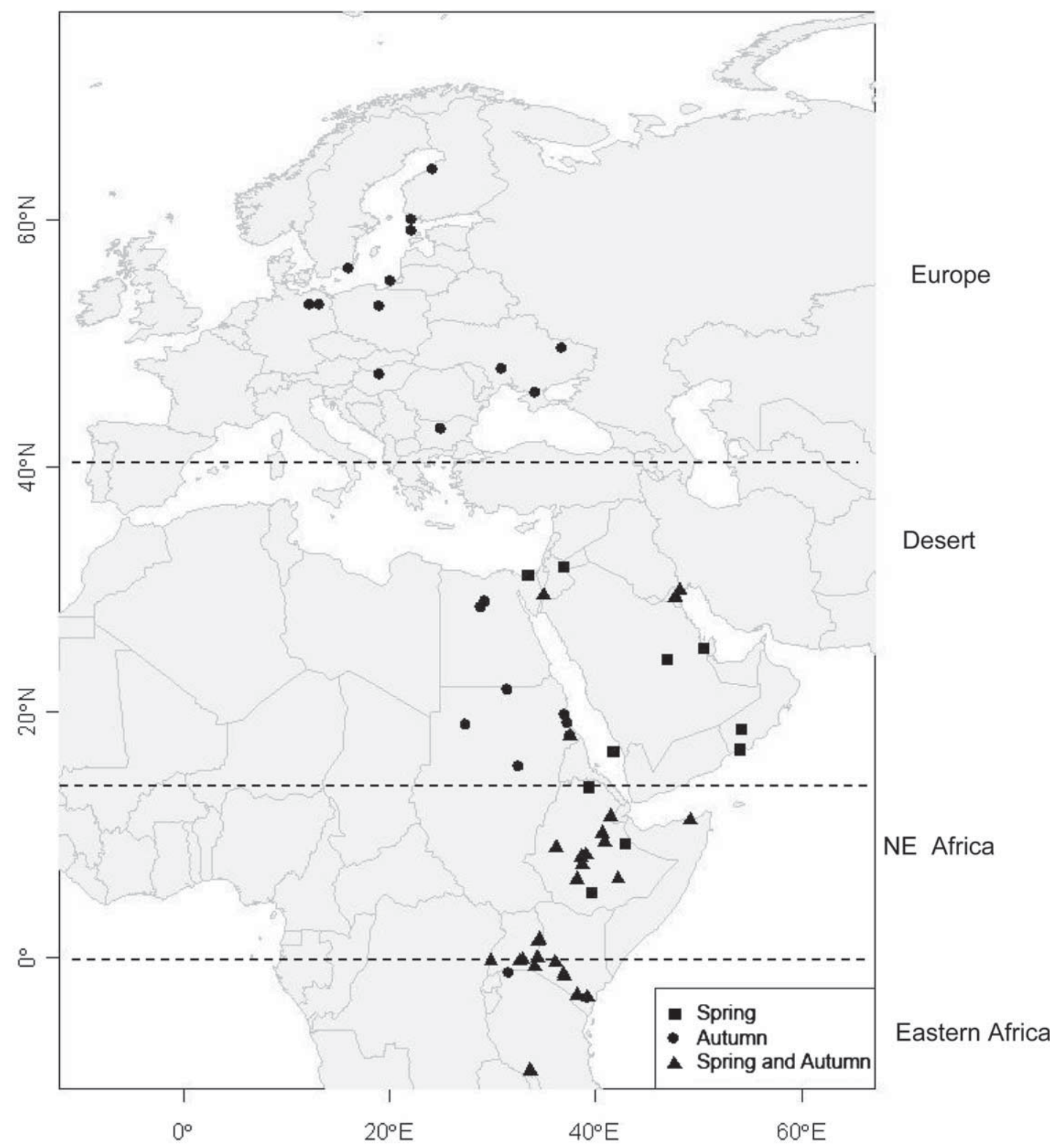

Figure 1. Geographic distribution of study sites and migration sectors. Triangle, hexagon and square symbols indicate study sites in autumn, spring, and both autumn and spring, respectively.

migration studies in northeast and eastern Africa, particu larly in Sudan (Nikolaus and Pearson 1982, Nikolaus 1983), Ethiopia (Ash 1980 and 1981, J. Ash unpubl. data, B. Biebach unpubl. data), Uganda (Pearson 1972 and unpubl. data, M. Fogden unpubl. data, M. Wilson unpubl. data), Kenya (Pearson and Backhurst 1976a,b and unpubl. data, Britton and Britton 1977 and unpubl. data), and Tanzania (L. and N. Baker unpubl. data, B. Biebach and U. Bauchinger unpubl. data). We considered data gathered from Egypt (Moreau 1961, Watson 1971, Goodman and Meininger 1989, B. Biebach and U. Bauchinger unpubl. data), Eritrea (Smith 1957), and Somalia (Archer and Godman 1961, Ash and Miskell 1998, J. Ash unpubl. data). We also used published and unpublished data sources from the Middle East and the Arabian regions. These include Israel (Safriel 1968, Safriel and Lavee 1988, Morgan and
Shirihai 1997), Jordan (J. Ash and R. Spencer unpubl. data, D. Pearson unpubl. data), Kuwait (Cleere et al. 2000 and unpubl. data), Oman and Saudi Arabia (G. Nikolaus, J. Ash, M. Evans and S. Newton unpubl. data). In addition, published migration information (e.g. Csörgö and Lövei 1995, Fransson 1995, Chernestov 1996, Lindström et al. 1996, Morgan and Shirihai 1997, Schmidt 1964, Bairlein 1997, Honza et al. 2000) were included in the analysis.

\section{The species}

The study focused on 11 species: the marsh warbler Acrocephalus palustris, sedge warbler Acrocephalus schoenobaenus, red backed shrike Lanius collurio, thrush nightingale Luscinia luscinia, nightingale Luscinia megarhynchos, spotted flycatcher Muscicapa striata, willow warbler Phylloscopus 
trochilus, garden warbler Sylvia borin, whitethroat Sylvia communis, lesser whitethroat Sylvia curruca and barred warbler Sylvia nisoria. Selection of the species was based on (but not exclusively dependent on) Pearson et al. (1988), and Pearson and Lack (1992). Our main focus was to include trans Saharan migrants that migrate along the eastern African flyway/migration route (taken here as the route through Sudan, Ethiopia, Eritrea, Egypt, Somalia, Kenya, Uganda and Tanzania) with different spatio temporal migration patterns (Cramp and Perrins 1992 and 1993). The distinction between migratory and winter ing birds was done according to the timing of migration described in Table 1. Some study sites in eastern Africa are also the wintering grounds for the species considered; hence in these locations both migrating and wintering birds might be present. The distinction between migratory and winter ing birds was made according to the timing of migration described by Ash (1981), Pearson et al. (1988), Pearson and Lack (1992), Cramp and Perrins (1992 and 1993) and D. Pearson (unpubl. data), Table 1.

\section{Data analysis}

Migration speed estimates

Seasonal migration speeds were measured based on median passage and/or arrival dates of a species at given study locations along the migration route. Median dates were measured as dates when the cumulative ringing distribution passed $50 \%$ of the total capture in a given location. Migration speed estimates of individual species were calculated on the basis of "Population speeds". This estimate considers the distances travelled and time elapsed for a given species rather than an individual. Linear regression models were applied to the median dates of migrations, with distance as the dependent variable and time elapsed as the independent variable. Migration speeds were determined from a total data set comprising 128,833 birds in autumn and 29,625 birds in spring.
Migration speed estimates along geographic sectors

We compared migration speed for each species in different geographic regions by dividing the eastern flyway into four different sectors according to basic geographical and ecolo gical conditions (Fig. 1). 1. European sector study sites located north of $40^{\circ}$ N. 2. Desert localities in the Middle East and North Africa between $35^{\circ} \mathrm{N}$ and $15^{\circ} \mathrm{N}$ including Kuwait, Jordan, Israel, Saudi Arabia, Oman, Egypt, northern and central Sudan and Eritrea. 3. North eastern Africa (NE Africa) regions in the eastern African flyway located between $15^{\circ} \mathrm{N}$ and $0^{\circ}$ equator (Central and southern Sudan, Ethiopia, Somalia, northern Kenya, northern and central Uganda). 4. Eastern Africa - localities between $0^{\circ}$ equator and $10^{\circ} \mathrm{S}$ in southern Kenya, southern Uganda and Tanzania).

We then measured autumn and spring migration speed during the journey across the four ecogeographic sectors. Due to limited passage data during spring migration in Europe, we used median arrival date (as given by Cramp and Perrins 1992, 1993) at northern latitude breeding sites (north of $40^{\circ} \mathrm{N}$ ) as a reference to estimate the speed between departure from the desert and arrival at breeding grounds. For some species and some migration sectors, median dates were reported from only two locations. In such cases, linear models could not be applied. Therefore, the speeds of migration were calculated by dividing the distance between the pairs of localities by the difference in median migration dates.

In brief, first we conducted a sector wise (Europe, desert, $\mathrm{NE}$ and eastern Africa) comparison of speed and analyzed the effect of timing and season on migration speed. Based on the sector wise speed estimates, we reconstructed the total duration of migration for each season. Duration was calculated from estimates of sector distances and the associated speed in the sector. Latitudinal sector distances were estimated to be 2,200, 2,000, 1,650 and 1,100 km for the Europe, desert, NE and eastern Africa sectors, respec tively. We compared the difference between spring and autumn migration using seasonal sector wise total duration

Table 1. Earliest arrival (autumn) and departure (spring) dates considered (as defined in Methods) for each species at study sites in East Africa. The signs $<$ and $>$ indicate before and after, respectively, the dates given in the table.

\begin{tabular}{|c|c|c|c|c|c|}
\hline \multirow[t]{2}{*}{ Species } & \multicolumn{5}{|c|}{ Study sites and migratory period (autumn (n), spring (n)) } \\
\hline & Ethiopia & Central Kenya & Uganda & Ngulia, Kenya & Tanzania \\
\hline Marsh warbler & $<$ Nov. 30 (53) & <Dec. 21 (108) & & <Dec. 18 (40803) & $\begin{array}{l}<\text { Jan. } 30(36) \\
>\text { Apr. } 5 \text { (45) }\end{array}$ \\
\hline Sedge warbler & $\begin{array}{l}\text { <Jan. } 22(40) \\
>\text { Apr. } 15(62)\end{array}$ & $\begin{array}{l}\text { < Dec. } 27 \text { (51) } \\
>\text { Apr. } 5 \text { (689) }\end{array}$ & $\begin{array}{l}\text { <Jan. } 20(92) \\
\text { > Mar. } 7(175)\end{array}$ & <Dec. 21 (52) & \\
\hline Red backed shrike & $>$ Apr. 2 (63) & $>$ Mar. 27 (63) & $<$ Nov. 11 (77) & $<$ Dec. 7 (1308) & >Mar. 11 (91) \\
\hline Thrush nightingale & <Dec. 5 (173) & $\begin{array}{l}<\text { Jan. } 12 \text { (59) } \\
>\text { Apr. } 20 \text { (53) }\end{array}$ & & <Dec. 15 (20686) & $\begin{array}{l}<\text { Jan. } 12(32) \\
>\text { Mar. } 14(104)\end{array}$ \\
\hline Nightingale & $\begin{array}{l}<\text { Nov. } 29(571) \\
>\text { Feb. } 27(63)\end{array}$ & & & <Dec. 12 (346) & \\
\hline Spotted flycatcher & $\begin{array}{l}<\text { Dec. } 5 \text { (38) } \\
>\text { Apr. } 23(135)\end{array}$ & & & & \\
\hline Willow warbler & $\begin{array}{l}<\text { Dec. } 6(60) \\
>\text { Mar. } 25(575)\end{array}$ & $\begin{array}{l}<\text { Dec. } 20(56) \\
>\text { Mar. } 3(1555)\end{array}$ & $\begin{array}{l}<\text { Dec. } 17 \text { (131) } \\
>\text { Mar. } 5 \text { (89) }\end{array}$ & $<$ Dec. 20 (1344) & $\begin{array}{l}<\text { Dec. } 25(99) \\
>\text { Mar. } 10(751)\end{array}$ \\
\hline Garden warbler & $\begin{array}{l}\text { <Nov. } 25 \text { (22) } \\
>\text { Apr. } 12(209)\end{array}$ & $\begin{array}{l}<\text { Jan. } 5(73) \\
>\text { Mar. } 25 \text { (257) }\end{array}$ & $\begin{array}{l}<\text { Dec. } 20 \text { (469) } \\
>\text { Mar. } 8 \text { (320) }\end{array}$ & <Dec. 30 (469) & $\begin{array}{l}\text { <Jan. } 21(210) \\
>\text { Mar. } 10(476)\end{array}$ \\
\hline Whitethroat & $\begin{array}{l}<\text { Nov. } 27 \text { (249) } \\
>\text { Mar. } 15 \text { (143) }\end{array}$ & $\begin{array}{l}<\text { Nov. } 25 \text { (42) } \\
>\text { Mar. } 31 \text { (265) }\end{array}$ & & <Dec. 18 (22191) & $\begin{array}{l}<\text { Dec. } 25(78) \\
>\text { Mar. } 10(401)\end{array}$ \\
\hline Lesser whitethroat & $\begin{array}{l}<\text { Oct. } 10(97) \\
>\text { Mar. } 5(108)\end{array}$ & & & & \\
\hline Barred warbler & $>$ Mar. 12 (21) & $>$ Mar. 21 (33) & & $<$ Dec. 18 (22191) & \\
\hline
\end{tabular}


estimates. Paired sampled t test was applied to compare variation between autumn and spring migration in each sector. Table 2 summarizes individual species passage date (covered in this study) across each geographic sector for both seasons.

\section{Results}

Autumn migration speed and median date showed a significant negative relationship in Europe $\left(\mathrm{r}^{2}=0.70\right.$, $\mathrm{P}<0.001$, Fig. 2a) whereby later departing species cover their migration with slower average migration speeds. In spring, the average migration speed in NE Africa increased with the progress of the season $\left(\mathrm{r}^{2}=0.75, \mathrm{P}<0.01\right.$, Fig. $3 \mathrm{c})$. During the northward migration late migrating species, such as marsh warbler, red backed shrike, spotted flycatcher and garden warbler, all migrated at a faster speed than did early migrating species.

Sector wise comparisons between autumn and spring duration (paired t test) indicate that migratory journeys are covered in a much shorter time $( \pm S E)$ in spring than in autumn (Fig. 4) in the desert (autumn: 16.83 \pm 0.93 vs. spring: $\left.12.15 \pm 0.79, \mathrm{n}=8, \mathrm{t}_{7}=14.77, \mathrm{P}<0.01\right)$, across Africa (NE Africa, autumn: $53.45 \pm 8.93$ vs. spring: $27.60 \pm 6.39, \mathrm{n}=8, \mathrm{t}_{7}=2.20, \mathrm{P}=0.04$ and East Africa, autumn: $52.17 \pm 5.83$; spring: $19.78 \pm 12.25, \mathrm{n}=7, \mathrm{t}_{6}=$ $5.49, \mathrm{P}<0.01)$. The time required to cover the distance in the northern latitude Europe for autumn and spring were equivalent (autumn: $20.20 \pm 0.62$ vs. spring: $22 \pm 2.88$, $\left.\mathrm{n}=11: \mathrm{t}_{10}=-0.58, \mathrm{P}=0.55\right)$.

\section{Discussion}

Results of this study indicate that along the sectors above $40^{\circ} \mathrm{N}$, species migrating later in the autumn cover their journey at a relatively slower average migration speed. These include species such as lesser whitethroat, garden warbler, spotted flycatcher, whitethroat and willow warbler. These findings are in agreement with the relationship of migration speed estimates and timing in Europe given by Alerstam and Lindström (1990). Several reasons have been proposed for the observed seasonal decline in speed including unfavourable and deteriorating environmental conditions such as shortened day length and food supplies (Alerstam and Lindström 1990, Ellegren 1993, Kvist and Lindström 2000, Hall and Fransson 2001, Alerstam 2003). In contrast, an increased migration speed in late migrants was observed during autumn migration in NE Africa for $\left(r^{2}=0.50, P=0.05\right.$, Fig. 2c) particularly for sedge warbler and spotted flycatcher.

Selection for faster migration speed that minimizes time and maximizes early arrival at final wintering/moulting quarters might be stronger for long distance migrants heading to wintering grounds south of $10^{\circ} \mathrm{N}$ than most short to medium distance migrants, such as those bound for tropical winter quarters north of $10^{\circ} \mathrm{N}$ (e.g. lesser whitethroat). Particularly later in the season, the migration speed should accommodate a time to cover the remaining distance southward and time to undergo moult before commencing return migration. Early arrival at the wintering grounds can also play an important role in competition for high quality resources and establish winter territories (Lindström and Alerstam 1992).

Although with different statistical significance levels, relatively higher migration speed in late departing Palearctic passerines seems to be a general pattern in all sectors during spring migration. Birds migrate at an accelerated speed particularly in the northern latitudes after leaving NE Africa and while moving through the desert. Moreover, late migrants migrate at a higher speed than early migrating passerines. Since early arrival at the breeding ground can play a major role in competition for resources and

Table 2. Autumn and spring passage dates across each geographic sector.

\begin{tabular}{|c|c|c|c|c|}
\hline \multirow[t]{2}{*}{ Species } & \multicolumn{4}{|c|}{ Geographic sector } \\
\hline & Europe & Desert & NE Africa & Eastern Africa \\
\hline \multirow{2}{*}{ Marsh warbler } & $8 / 18 \quad 9 / 21$ & $8 / 269 / 24$ & $9 / 7 \quad 11 / 22$ & $11 / 22 \quad 12 / 29$ \\
\hline & $5 / 9 \quad 5 / 25$ & $5 / 6 \quad 5 / 17$ & $5 / 15 / 7$ & $4 / 12 \quad 5 / 7$ \\
\hline \multirow[t]{2}{*}{ Sedge warbler } & $8 / 10 \quad 9 / 5$ & $8 / 319 / 7$ & $11 / 25 \quad 12 / 11$ & $12 / 5 \quad 12 / 19$ \\
\hline & $4 / 25 \quad 5 / 8$ & $4 / 29 \quad 5 / 8$ & & $3 / 30 \quad 4 / 26$ \\
\hline \multirow[t]{2}{*}{ Red backed shrike } & $8 / 29 \quad 9 / 15$ & $9 / 79 / 15$ & & $11 / 18 \quad 11 / 24$ \\
\hline & $5 / 6 \quad 5 / 26$ & $4 / 28 \quad 5 / 6$ & $4 / 2 \quad 4 / 28$ & $4 / 4 \quad 4 / 24$ \\
\hline \multirow[t]{2}{*}{ Thrush nightingale } & $8 / 24 \quad 9 / 16$ & $8 / 30 \quad 9 / 7$ & $10 / 4 \quad 11 / 27$ & $11 / 28 \quad 12 / 17$ \\
\hline & & $4 / 265 / 2$ & & $3 / 20 \quad 4 / 25$ \\
\hline \multirow[t]{2}{*}{ Nightingale } & & & $9 / 23 \quad 11 / 23$ & \\
\hline & $3 / 20 \quad 4 / 16$ & $4 / 6 \quad 4 / 22$ & $3 / 20 \quad 4 / 22$ & \\
\hline \multirow[t]{2}{*}{ Spotted flycatcher } & $8 / 27 \quad 9 / 16$ & $9 / 8 \quad 9 / 16$ & $10 / 18 \quad 11 / 30$ & \\
\hline & $5 / 7 \quad 5 / 26$ & $5 / 1 \quad 5 / 16$ & $4 / 26 \quad 5 / 1$ & \\
\hline \multirow[t]{2}{*}{ Willow warbler } & $8 / 27 \quad 9 / 5$ & $9 / 3 \quad 9 / 15$ & $10 / 20 \quad 11 / 7$ & $11 / 8 \quad 12 / 12$ \\
\hline & $4 / 25 \quad 5 / 13$ & $4 / 25 \quad 5 / 2$ & $4 / 22 \quad 4 / 28$ & $3 / 194 / 24$ \\
\hline \multirow[t]{2}{*}{ Garden warbler } & $9 / 1 \quad 10 / 1$ & $9 / 10 \quad 9 / 31$ & $10 / 4 \quad 11 / 20$ & $11 / 22 \quad 12 / 30$ \\
\hline & $5 / 6 \quad 5 / 30$ & $5 / 6 \quad 5 / 11$ & $4 / 25 \quad 5 / 9$ & $3 / 194 / 25$ \\
\hline \multirow[t]{2}{*}{ Whitethroat } & $8 / 28 \quad 9 / 15$ & $9 / 7 \quad 9 / 15$ & $10 / 11 \quad 11 / 8$ & $11 / 9 \quad 12 / 12$ \\
\hline & $4 / 25 \quad 5 / 16$ & $4 / 24 \quad 5 / 4$ & $3 / 214 / 26$ & $3 / 164 / 9$ \\
\hline \multirow[t]{2}{*}{ Lesser whitethroat } & $9 / 39 / 23$ & $9 / 12 \quad 9 / 23$ & & \\
\hline & $4 / 6 \quad 4 / 29$ & $3 / 30 \quad 4 / 24$ & $3 / 194 / 26$ & \\
\hline \multirow[t]{2}{*}{ Barred warbler } & $8 / 15$ 9/8 & & & \\
\hline & $5 / 5 \quad 5 / 31$ & & $3 / 15 \quad 4 / 20$ & $3 / 21 \quad 4 / 21$ \\
\hline
\end{tabular}



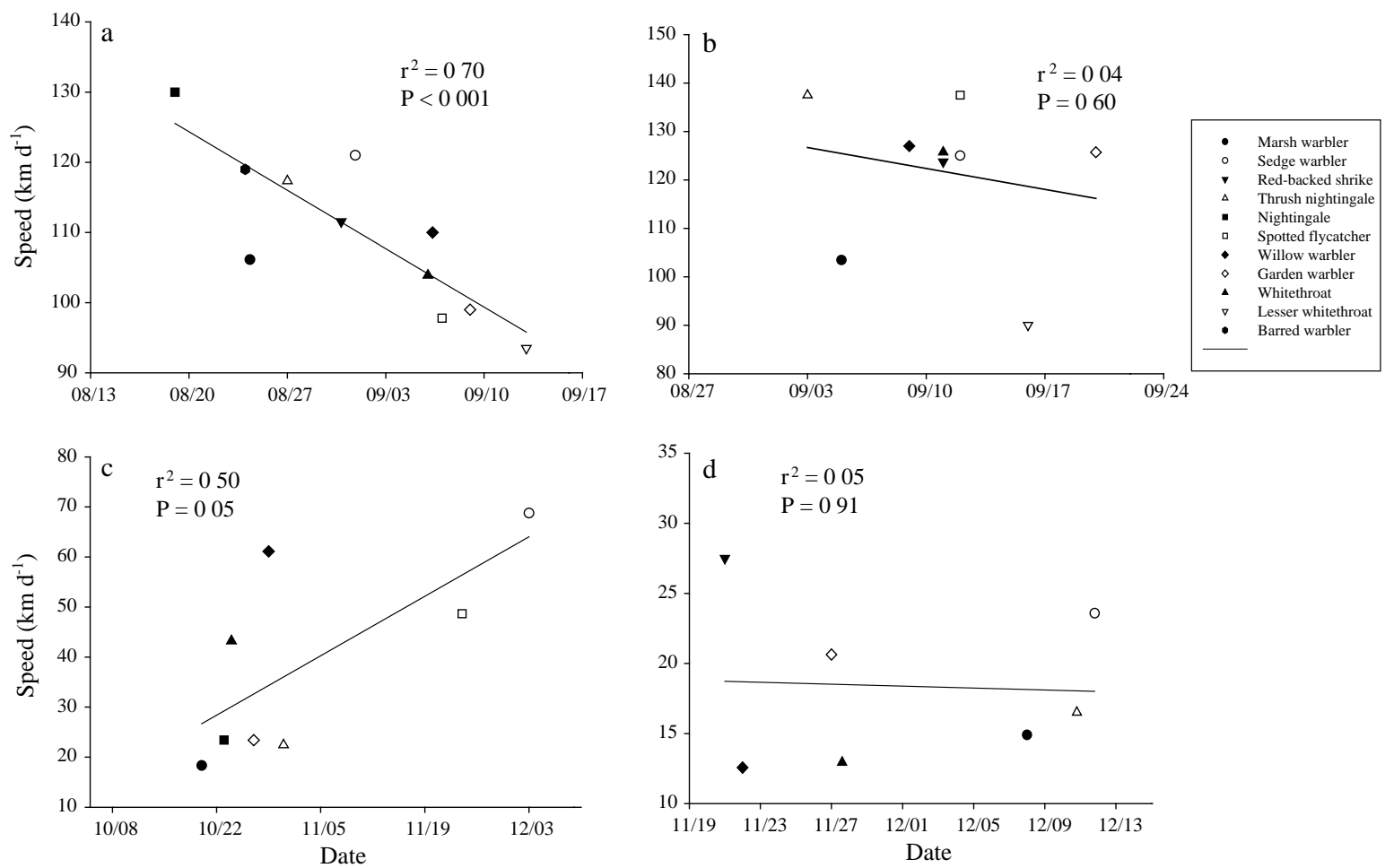

Figure 2. Relationship between the autumn median migration date and average seasonal migration speed in Europe (a), desert (b), NE Africa (c) and eastern Africa (d) sectors.

reproduction (e.g. Lozano et al. 1996), selection for fast increase in day length, hence longer fuel deposition times spring migration may be favoured. Higher migration speed in late spring migrants may be favoured by the rapid

(Bauchinger and Klaassen 2005). Overall, the spotted flycatcher showed a characteristic migration pattern of
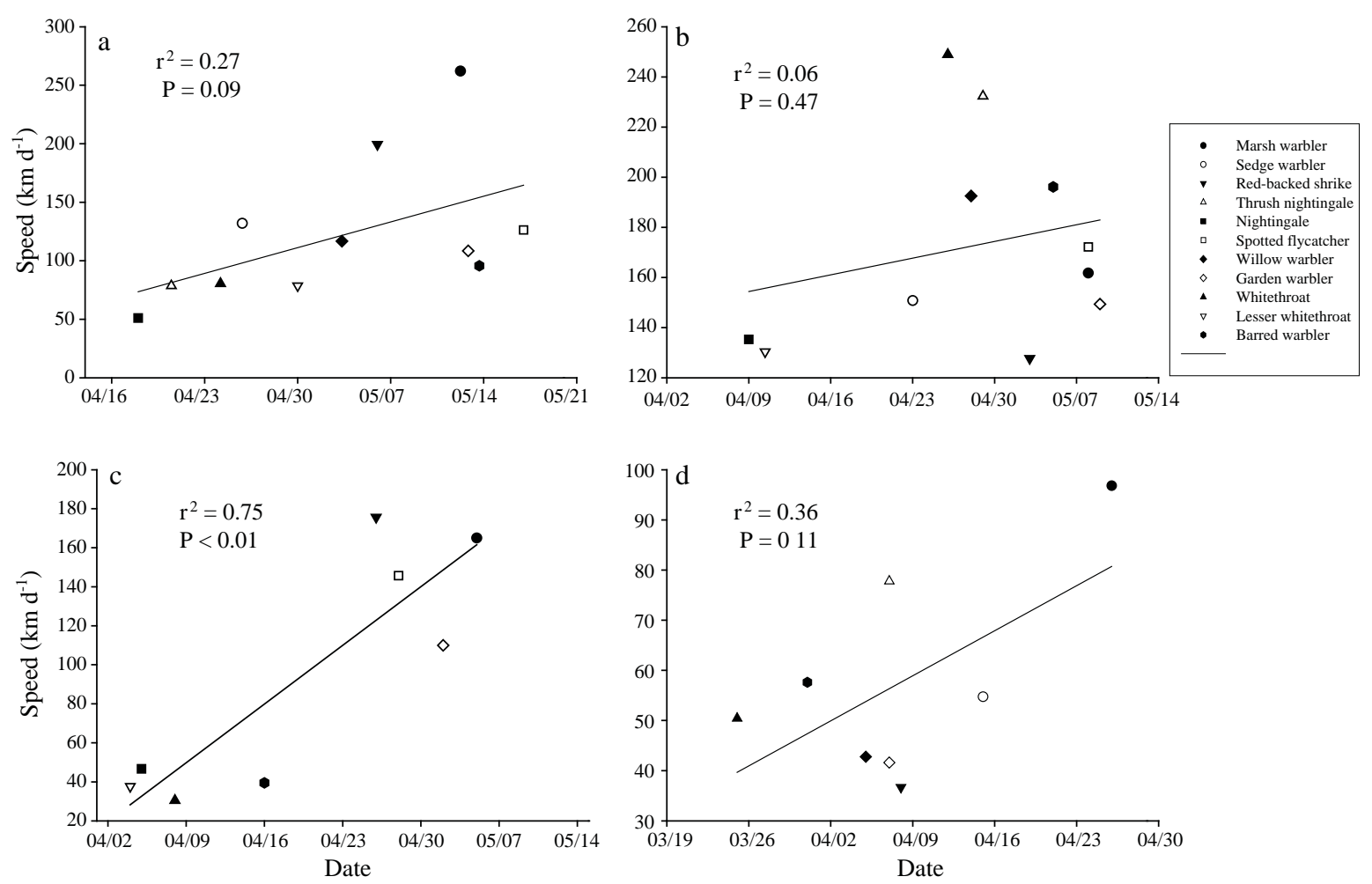

Figure 3. Relationship between the spring median migration date and average seasonal migration speed at breeding sites in Europe (a), desert (b), NE Africa (c) and eastern Africa (d) sectors. 

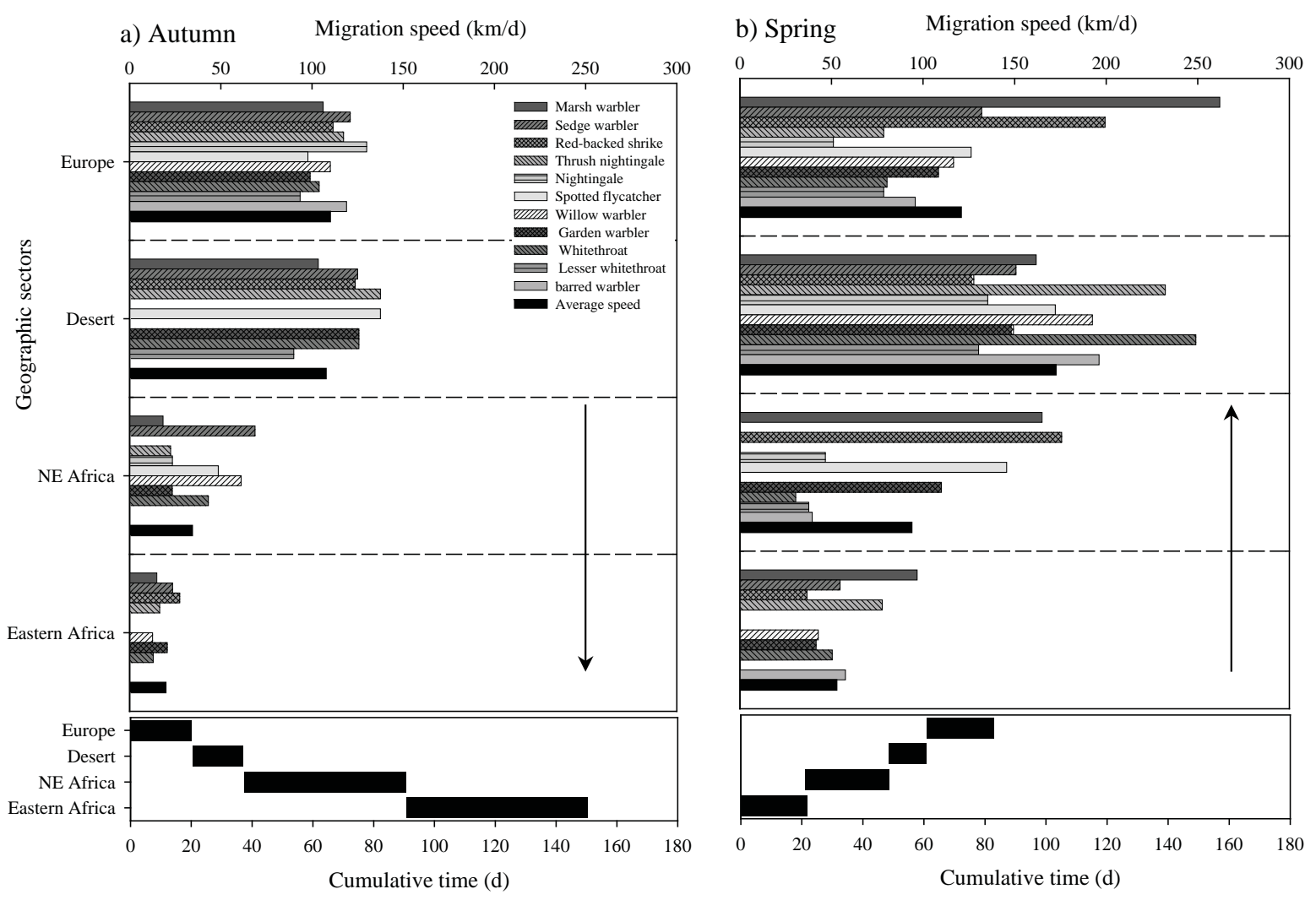

Figure 4. Sector wise comparisons between autumn (a), and spring (b) migration duration. Average speed represents sector mean migration speed while cumulative time indicates average cumulative number of days required by the study species to migrate across each geographic sector. Arrows show seasonal migration directions.

relatively late departure but high speed in both autumn and spring (Figs. 2 and 3). Similarly, the marsh warbler showed a late departure but high speed migration strategy, particu larly during spring. Most of the other species showed a varying departure time and speed of migration across the different sectors (Table 2).

Sector wise comparison of total duration indicates that birds migrate at a high autumn speed before reaching NE Africa followed by a lower speed and prolonged duration. One explanation for the lower migration speed in Africa is that several migratory species carry out moult between $8^{\circ}$ and $11^{\circ} \mathrm{N}$ in NE Africa and interrupt migration. According to Pearson et al. (1988) and Jenni and Winkler (1994), most adults and a few juveniles of sedge warbler and whitethroat (mainly the race icterops) undergo partial moult and occasionally a complete moult. All adult marsh warblers undergo a partial body and primary moult before they resume migration to southerly located sites, where complete moult occurs. The two Luscinia species in this study also exhibit a rather extended stay in NE Africa.

The timing and speed of migration to the tropics and within the tropics follows a pattern that is synchronized with the successive availability of favourable conditions generated by seasonal climatic factors related to rainfall (Pearson 1990). Once the ecological barriers are crossed, passerines face relatively 'suitable' conditions and can afford a longer stopover and/or a slower journey. This may allow birds to minimize energy expenditure and predation risk. Thus, long distance tropical migrants may have been selected for maximizing migration speed in the first two sectors of autumn migration before crossing the ecological barriers and for minimizing energy expenditure and predation risk during the second stage of their migration in Africa.

Sector wise seasonal comparison of migration duration indicates that migration journey in the African sectors and desert are covered in a much shorter time in spring than in autumn. These results support the general notation that migration speed is generally higher in spring than in autumn (Fransson 1995). Mean migration time between northern latitude breeding grounds and desert was nearly the same for both seasons. Similarly, Raess (2008) reported no significant difference between autumn and spring migration speed estimates for Siberian stonechats Saxicola torquata maura on migration across Central and northern Asia. Duration along this sector in the two seasons might be governed by different factors. Faster journey during autumn in Europe might be due to the need to cross the ecological barriers before food supplies and fattening conditions deteriorate. In spring, passerines migrants may fall under strict time pressure for timely arrival at the breeding grounds and with regard to competition for better quality breeding territories and mates (e.g. Kokko 1999).

\section{Conclusions}

The results of this study show that migration speed varies between different geographic sectors along the migration route, indicating that birds might optimally modulate their 
migration speed according to specific ecological and physiological demands en route. Optimal migration speed that minimizes time dependent costs and risks associated en route, but enhances arrival at a required destination before competitors is essential for organizing birds' annual cycles. Migration speed that incorporates demanding migratory activities and other life history phases across varying geographic sectors might be an important factor in determining the migratory strategy and distribution of birds.

Generally, our migration speed measurements are in line with earlier studies on long distance passerine migrants given by Hyytiä and Vikberg (1973), Hildén and Saurola (1982), Hedenström and Petterson (1987), Ellegren (1990, 1993), and Fransson (1995). However, in a study that compared spring and autumn speeds in five Sylvia species migrating using ringing recoveries across Europe, Fransson (1995) reported average $( \pm S E M)$ migration speeds of $91.6 \pm 6.4 \mathrm{~km} /$ day and $138.0 \pm 15.5 \mathrm{~km} /$ day in autumn and spring, respectively. Our population speed estimates in Europe differed from Fransson's (1995) individual speed values. Part of the explanation for the observed difference might be due to duration estimate biases from the ringing data we used. In autumn, we have used data points from individual birds trapped and ringed at bird observatories to measure median dates and 'population speed'. In spring, due to limited passage data available for each species, we have restricted estimates from median arrival dates at breeding grounds.

Theoretically, species specific life history strategies such as rate and frequency of annual moult and the migratory routes and distances, would regulate the migration speed in both seasons. Consistent with these concepts is that migration speed is regulated by an endogenous time program (Gwinner 1986, 1996a,b) that has been shaped by both spatial (e.g. Fransson et al. 2001) and temporal environmental factors, such as spatial distribution of suitable stopover areas and ecological barriers along the route (Terrill 1988).

Acknowledgements This study comprises analysis of data collected from several study sites. We acknowledge all the authorities and persons involved in the projects and those who supplied the data for the study (see Methods). Special thanks to John Ash for kindly allowing us to use his dataset. We thank R. E. Johnson, M. Raess, $\mathrm{K}$. Sengi ong and three anonymous reviewers for their valuable comments. The financial support was provided by the Austrian Academic Exchange Service and Max Planck Research Centre for Ornithology, Andechs. We thank Prof. Ellen Thaler and the late Eberhard Gwinner for valuable support during the study.

\section{References}

Alerstam, T. 2003. Bird migration speed. In: Berthold, P., Gwinner, E. and Sonnenschein, E. (eds). Avian migration. Springer Verlag, Berlin, Heidelberg, New York, pp. 253267.

Alerstam and Lindström 1990. Optimal bird migration: the relative importance of time, energy, and safety. In: Gwinner, E. (ed.). Bird migration: physiology and ecophysiology. Springer Verlag, Berlin, pp. 331351.
Archer, G. and Godman, E. M. 1961. The birds of British Somaliland and the Gulf of Aden, Vol. 3 4. Oliver and Boyd, London.

Ash, J. S. 1980. Migrational status of Palaearctic birds in Ethiopia. Proc. IV Pan Afr. Orn. Cong.: 199208.

Ash, J. S. 1981. Bird ringing results and ringed bird recoveries in Ethiopia. Scopus 5: 85101.

Ash, J. S. and Miskell, J. E. 1998. Birds of Somalia. Roberts bridge, U.K.

Bairlein, F. 1997. Spatio temporal course, ecology and energetics of western Palaearctic African songbird migration. Summary report 1994 1996. Institut für Vogelforschung, Wilhelm shaven.

Bauchinger, U. and Klaassen, M. 2005. Longer days in spring than in autumn accelerate migration speed of passerine birds. J. Avian Biol 36: 35 .

Britton, P. L. and Britton, B. A. 1977. An April fall of Palaearctic migrants at Ngulia. Scopus 1: 109111.

Chernestov, N. 1996. Preliminary hypotheses on migration of the sedge warbler (Acrocephalus schoenobaenus) in the eastern Baltic. Vogelwarte 38: 201210.

Cleere, N., Kelly, D. and Pilcher, C. W. T 2000. Result from late autumn ringing project in Kuwait, $1995 . \quad$ Ring. \& Migr. 20: 186190

Cramp, S. and Perrins, C. M. 1992. Handbook of the birds of Europe, the Middle East and North Africa: the birds of the western Palaearctic. Vol. VI. Warblers. Oxford University Press.

Cramp, S. and Perrins, C. M. 1993. Handbook of the birds of Europe, the Middle East and North Africa: the birds of the western Palaearctic. Vol. VII. Flycatchers to Shrikes. Oxford University Press.

Csörgö, T and Lövei, G. L. 1995. Autumn migration and recurrence of the thrush nightingale Luscinia luscinia at a stopover site in central Hungary. Ardeola 42: 5768.

Ellegren, H. 1990. Autumn migration speed in Scandinavian bluethroats, Luscinia s. svecica, during autumn migration in Sweden. Ring. \& Migr. 11: 121131.

Ellegren, H. 1993. Speed of migration and migratory flight lengths of passerine birds ringed during autumn migration in Sweden. Ornis. Scand. 24: 220228.

Fransson, T. 1995. Timing and speed of migration in North and West European populations of Sylvia warblers. J. Avian Biol. 26: 3948 .

Fransson, T., Jakobsson, S., Johannsson, P., Kullberg, C., Lind, J. and Vallin, A. 2001. Magnetic cues trigger extensive refuelling. Nature 414: 3536.

Goodman, S. M. and Meininger, P. L. 1989. The birds of Egypt. Oxford University Press.

Gwinner, E. 1986. Circannual rhythms in control of avian migrations. Adv. Study Behav. 16: 191228.

Gwinner, E. 1996a. Circannual clocks in avian reproduction and migration. Ibis 138: 4763 .

Gwinner, E. 1996b. Circadian and circannual clocks in avian migration. J. Exp. Biol. 199: 3948.

Hall, K. S. S. and Fransson, T. 2001. Wing moult in relation to autumn migration in adult common whitethroats Sylvia communis communis. Ibis 143: 580586.

Hedenström, A. and Petterson, J. 1987. Migration routes and wintering areas of willow warblers Phyloscopus trochilus ringed in Fennoscandia. Ornis Fenn. 64: 137143.

Hildén, O. and Saurola, P. 1982. Speed of autumn migration of birds ringed in Finland. Ornis Fenn. 59: 140143.

Honza, M., Literak, I., Pavelka, J. and Formanek, J. 2000. Postbreeding occurrence of the marsh warbler Acrocphalus palustris in reedbed areas in the Czech Republic and its migration to Africa. kologie der Vögel 22: 119129. 
Hyytiä, K. and Vikberg, P. 1973. Autumn migration and moult of the spotted flycatcher Muscicapa striata and the pied flycatcher Ficedula hypoleuca at the Signilskär bird station. Ornis Fenn. 50: 134143

Jenni, L. and Winkler, R. 1994. Moult and ageing of European passerines. Academic Press, London.

Kokko, H. 1999. Competition for early arrival in migratory birds. J. Anim. Ecol. 68: 940950

Kvist, A. and Lindström, Å. 2000. Maximum daily energy intake: it takes time to lift the metabolic ceiling. Physiol. Biochem. Zool. 73: 3036.

Lindström, A. and Alerstam, T. 1992. Optimal fat loads in migrating birds: a test of the time minimization hypothesis. Am. Nat. 140: 477491.

Lindström, Å., Hedenström, A. and Pettersson, J. 1996. The autumn migration of willow warbler Phylloscopus trochilus in Sweden: results from a nation wide co operative project. Ornis Svecica 6: 145172.

Lozano, G. A., Perreault, S. and Lemon, R. E. 1996. Age, arrival date and reproductive success of male American redstarts Setophaga ruticilla. J. Avian Biol. 27: 164170.

Moreau, R. E. 1961. Problems of Mediterranean Saharan migra tion. Ibis 103: 373427.

Morgan, J. H. and Shirihai, H. 1997. Passerines and passerine migration in Eilat. Int. Birdw. Centr. Eilat. Tech. Publ. 6: 150.

Nikolaus, G. 1983. An important passerine ringing site near the Sudan Red Sea coast. Scopus 7: 1518.

Nikolaus, G. and Pearson, D. J. 1982. Autumn passage of marsh warblers Acrocephalus palustris and sprossers Luscinia luscinia on the Sudan Red Sea coast. Scopus 6: 1719.

Pearson, D. J. 1972. The wintering and migration of some Palaearctic passerines at Kampala, Southern Uganda. Ibis 114: 4360 .

Pearson, D. J. 1990. Palaearctic passerine migrants in Kenya and Uganda: temporal and spatial patterns of their movements.

In: Gwinner, E. (ed.). Bird migration: physiology and ecophysiology. Springer Verlag, Berlin, pp. 4459.
Pearson, D. J. and Backhurst, G. C. 1976a. The southward migration of Palaearctic birds over Ngulia, Kenya. Ibis 118: 78105.

Pearson, D. J. and Backhurst, G. C. 1976b. Palaearctic passerine migration at Kariobangi, Nairobi. EANHS Bulletin 1976: 2328.

Pearson, D. J. and Lack, P. 1992. Migration patterns and habitat use by passerine and near passerine migrant birds in eastern Africa. Ibis 134: 8998.

Pearson, D. J., Nikolaus, G. and Ash, J. S. 1988. The Southward migration of Palaearctic passerines through northeast and east tropical Africa: a review. Proc. VI Pan Afr. Orn. Congr.: 243262.

Raess, M. 2008. Continental efforts: migration speed in spring and autumn in an inner Asian migrant. J. Avian Biol. 39: 1318.

Safriel, U. N. 1968. Bird migration in Eilat, Israel. Ibis 110: 283320.

Safriel, U. N. and Lavee, D. 1988. Weight changes of cross desert migrants at an oasis do energetic considerations along deter mine the length of stopover? Oecologia 76: 611619.

Schmidt, E. 1964. Untersuchungen an einigen Holunder fressen den Singvögeln in Ungarn. Zool. Abh. Mus. Tierkde. Dresden 27: 1128.

Smith, K. D. 1957. An annotated check list of the birds of Eritrea. Ibis 120: 480497.

Terrill, S. B. 1988. The relative importance of ecological factors in bird migration. Proc. XIX Int. Ornithol. Congr.: 2180 2190.

Watson, G. E. 1971. A serological and ectoparasite survey of migratory birds in northeast Africa. Smithsonian Institution, Washington.

Weber, T. P. and Houston, A. I. 1997. A general model for time minimising avian migration. J. Avian Biol. 185: 447458.

Weber, T. P., Houston, A. I. and Ens, B. J. 1998. Optimal avian migration: a dynamic model of fuel stores and site use. Evol. Ecol. 12: 377401 
Appendix 1.

\begin{tabular}{|c|c|c|c|c|c|}
\hline Country & Study site & Location & & & \\
\hline \multirow[t]{3}{*}{ Finland } & Tauvo & $64^{\circ} 08^{\prime} \mathrm{N}, 24^{\circ} 06^{\prime} \mathrm{E}$ & Uganda & Gaba & $00^{\circ} 06^{\prime} \mathrm{S}, 32^{\circ} 55^{\prime} \mathrm{E}$ \\
\hline & Rauvola & $60^{\circ} 04^{\prime} \mathrm{N}, 22^{\circ}, 03^{\prime} \mathrm{E}$ & & Kaazi & $00^{\circ} 12^{\prime} \mathrm{S}, 32^{\circ} 37^{\prime} \mathrm{E}$ \\
\hline & Hanko & $59^{\circ} 08^{\prime} \mathrm{N}, 22^{\circ} 09^{\prime} \mathrm{E}$ & & Katalemiya & $00^{\circ} 38^{\prime} \mathrm{S}, 34^{\circ} 05^{\prime} \mathrm{E}$ \\
\hline Sweden & Ottenby & $56^{\circ} 02^{\prime} \mathrm{N}, 16^{\circ} 04^{\prime} \mathrm{E}$ & & NW Elgon at Tegeres & $01^{\circ} 25^{\prime} \mathrm{N}, 34^{\circ} 25^{\prime} \mathrm{E}$ \\
\hline Russia & Rybachy & $55^{\circ} 02^{\prime} \mathrm{N}, 20^{\circ} 08^{\prime} \mathrm{E}$ & & Lake Bisina & $01^{\circ} 35^{\prime} \mathrm{N}, 34^{\circ} 31^{\prime} \mathrm{E}$ \\
\hline \multirow{2}{*}{ Germany } & Galenbecker See & $53^{\circ} 06^{\prime} \mathrm{N}, 13^{\circ} 07^{\prime} \mathrm{E}$ & & Mweya/Lake Edward/ & $00^{\circ} 10^{\prime} \mathrm{S}, 29^{\circ} 50^{\prime} \mathrm{E}$ \\
\hline & Reit & $53^{\circ} 05^{\prime} \mathrm{N}, 12^{\circ} 16^{\prime} \mathrm{E}$ & & QENP & \\
\hline Poland & Mierzeja Wislana & $53^{\circ} 03^{\prime} \mathrm{N}, 19^{\circ} 03^{\prime} \mathrm{E}$ & Tanzania & Kifufu & $03^{\circ} 09^{\prime} \mathrm{S}, 39^{\circ} 12^{\prime} \mathrm{E}$ \\
\hline Hungary & Budakeszi & $47^{\circ} 31^{\prime} \mathrm{N}, 18^{\circ} 56^{\prime} \mathrm{E}$ & & Mufindi & $09^{\circ} 05^{\prime} \mathrm{S}, 33^{\circ} 40^{\prime} \mathrm{E}$ \\
\hline \multirow[t]{3}{*}{ Ukraine } & Taranqut & $45^{\circ} 57^{\prime} \mathrm{N}, 34^{\circ} 14^{\prime} \mathrm{E}$ & & & \\
\hline & Malachoni Liman & $49^{\circ} 35^{\prime} \mathrm{N}, 36^{\circ} 47^{\prime} \mathrm{E}$ & & & \\
\hline & Stephanovika & $47^{\circ} 53^{\prime} \mathrm{N}, 30^{\circ} 53^{\prime} \mathrm{E}$ & & & \\
\hline Bulgaria & Central Bulgaria & $43^{\circ} 00^{\prime} \mathrm{N}, 25^{\circ} 00^{\prime} \mathrm{E}$ & & & \\
\hline \multirow[t]{6}{*}{ Sudan } & Kho Barak & $18^{\circ} 03^{\prime} \mathrm{N}, 37^{\circ} 30^{\prime} \mathrm{E}$ & & & \\
\hline & $\mathrm{K}^{\prime}$ Arbaat & $19^{\circ} 48^{\prime} \mathrm{N}, 37^{\circ} 03^{\prime} \mathrm{E}$ & & & \\
\hline & Wadihalfa & $21^{\circ} 50^{\prime} \mathrm{N}, 31^{\circ} 25^{\prime} \mathrm{E}$ & & & \\
\hline & Suakin & $19^{\circ} 06^{\prime} \mathrm{N}, 37^{\circ} 18^{\prime} \mathrm{E}$ & & & \\
\hline & Suakin Mangrooves & $19^{\circ} 02^{\prime} \mathrm{N}, 27^{\circ} 23^{\prime} \mathrm{E}$ & & & \\
\hline & Khartoum & $15^{\circ} 38^{\prime} \mathrm{N}, 32^{\circ} 33^{\prime} \mathrm{E}$ & & & \\
\hline \multirow[t]{2}{*}{ Egypt } & Sadat Farm & $28^{\circ} 30^{\prime} \mathrm{N}, 28^{\circ} 55^{\prime} \mathrm{E}$ & & & \\
\hline & Desert Station & $29^{\circ} 00^{\prime} \mathrm{N}, 29^{\circ} 20^{\prime} \mathrm{E}$ & & & \\
\hline Tanzania & Kikuru Reserve & $01^{\circ} 12^{\prime} \mathrm{S}, 31^{\circ} 35^{\prime} \mathrm{E}$ & & & \\
\hline \multicolumn{6}{|l|}{ b) Spring: } \\
\hline Country & Studysite & Location & & & \\
\hline \multirow[t]{3}{*}{ Ethiopia } & Debre Mariam Islands & $13^{\circ} 56^{\prime} \mathrm{N}, 39^{\circ} 22^{\prime} \mathrm{E}$ & & & \\
\hline & Negele & $05^{\circ} 20^{\prime} \mathrm{N}, 39^{\circ} 36^{\prime} \mathrm{E}$ & & & \\
\hline & Jijiga & $09^{\circ} 22^{\prime} \mathrm{N}, 42^{\circ} 51^{\prime} \mathrm{E}$ & & & \\
\hline Jordan & Azraq & $31^{\circ} 49^{\prime} \mathrm{N}, 36^{\circ} 49^{\prime} \mathrm{E}$ & & & \\
\hline \multirow[t]{2}{*}{ Oman } & Dauka & $18^{\circ} 40^{\prime} \mathrm{N}, 54^{\circ} 04^{\prime} \mathrm{E}$ & & & \\
\hline & Salalh Sunfarm & $17^{\circ} 00^{\prime} \mathrm{N}, 54^{\circ} 00^{\prime} \mathrm{E}$ & & & \\
\hline Egypt & Sinai/Israel & $31^{\circ} 08^{\prime} \mathrm{N}, 33^{\circ} 25^{\prime} \mathrm{E}$ & & & \\
\hline \multirow[t]{3}{*}{ Saudi Arabia } & Farasan & $16^{\circ} 52^{\prime} \mathrm{N}, 41^{\circ} 41^{\prime} \mathrm{E}$ & & & \\
\hline & El'Hair & $24^{\circ} 21^{\prime} \mathrm{N}, 46^{\circ} 57^{\prime} \mathrm{E}$ & & & \\
\hline & Karan & $24^{\circ} 72^{\prime} \mathrm{N}, 49^{\circ} 83^{\prime} \mathrm{E}$ & & & \\
\hline \multicolumn{6}{|c|}{ c) Autumn and Spring: } \\
\hline Country & Studysite & Location & & & \\
\hline \multirow[t]{3}{*}{ Kuwait } & Jahara & $29^{\circ} 19^{\prime} \mathrm{N}, 47^{\circ} 40^{\prime} \mathrm{E}$ & & & \\
\hline & Sulaibikhart & $29^{\circ} 18^{\prime} \mathrm{N}, 47^{\circ} 49^{\prime} \mathrm{E}$ & & & \\
\hline & Um Rimam & $29^{\circ} 55^{\prime} \mathrm{N}, 47^{\circ} 71^{\prime} \mathrm{E}$ & & & \\
\hline Israel & Eilat & $29^{\circ} 33^{\prime} \mathrm{N}, 34^{\circ} 57^{\prime} \mathrm{E}$ & & & \\
\hline Sudan & Kho Barak & $18^{\circ} 03^{\prime} \mathrm{N}, 37^{\circ} 30^{\prime} \mathrm{E}$ & & & \\
\hline \multirow[t]{10}{*}{ Ethiopia } & Abijata & $07^{\circ} 36^{\prime} \mathrm{N}, 38^{\circ} 40^{\prime} \mathrm{E}$ & & & \\
\hline & Bahadu & $10^{\circ} 11^{\prime} \mathrm{N}, 40^{\circ} 37^{\prime} \mathrm{E}$ & & & \\
\hline & Gambella & $08^{\circ} 15^{\prime} \mathrm{N}, 38^{\circ} 35^{\prime} \mathrm{E}$ & & & \\
\hline & Koka & $08^{\circ} 27^{\prime} \mathrm{N}, 39^{\circ} 06^{\prime} \mathrm{E}$ & & & \\
\hline & Aseita/Harar & $11^{\circ} 34^{\prime} \mathrm{N}, 41^{\circ} 27^{\prime} \mathrm{E}$ & & & \\
\hline & Didessa & $09^{\circ} 02^{\prime} \mathrm{N}, 36^{\circ} 09^{\prime} \mathrm{E}$ & & & \\
\hline & Bulcha & $06^{\circ} 27^{\prime} \mathrm{N}, 38^{\circ} 11^{\prime} \mathrm{E}$ & & & \\
\hline & Imi & $06^{\circ} 28^{\prime} \mathrm{N}, 42^{\circ} 10^{\prime} \mathrm{E}$ & & & \\
\hline & Afdem River & $09^{\circ} 30^{\prime} \mathrm{N}, 40^{\circ} 49^{\prime} \mathrm{E}$ & & & \\
\hline & Bosasso/Somalia & $11^{\circ} 16^{\prime} \mathrm{N}, 49^{\circ} 10^{\prime} \mathrm{E}$ & & & \\
\hline \multirow[t]{4}{*}{ Kenya } & Ngulia & $03^{\circ} 00^{\prime} \mathrm{S}, 38^{\circ} 13^{\prime} \mathrm{E}$ & & & \\
\hline & Karibangi NB & $01^{\circ} 15^{\prime} \mathrm{S}, 36^{\circ} 53^{\prime} \mathrm{E}$ & & & \\
\hline & Athi River & $01^{\circ} 26^{\prime} \mathrm{S}, 36^{\circ} 58^{\prime} \mathrm{E}$ & & & \\
\hline & Lake Nakuru & $00^{\circ} 20^{\prime} \mathrm{S}, 36^{\circ} 06^{\prime} \mathrm{E}$ & & & \\
\hline \multirow{2}{*}{$\begin{array}{l}\text { Kenya/Uganda } \\
\text { border }\end{array}$} & Nyanza/Ng'iya/ & $00^{\circ} 04^{\prime} \mathrm{N}, 34^{\circ} 22^{\prime} \mathrm{E}$ & & & \\
\hline & Lake Victoria are & & & & \\
\hline
\end{tabular}

